\title{
Characteristics of the dairy farmers who perform financial management in Paraná State, Brazil
}

\author{
Roney Zimpel ${ }^{1}$, Ferenc Istvan Bánkuti ${ }^{*}$, Maximiliane Alavarse Zambom ${ }^{3}$, Kellen Cristina \\ Kuwahara ${ }^{4}$, Sandra Mara Schiavi Bánkuti ${ }^{5}$
}

\author{
${ }^{1}$ University of Florida, Animal Science Department, Gainesville, FL, USA. \\ ${ }^{2}$ Universidade Estadual de Maringá, Departamento de Zootecnia, Maringá, PR, Brazil. \\ ${ }^{3}$ Universidade Estadual do Oeste do Paraná, Centro de Ciências Agrárias, Marechal Cândido Rondon, PR, Brazil. \\ ${ }^{4}$ Universidade Estadual de Maringá, Programa de Pós-graduação em Zootecnia, Maringá, PR, Brazil. \\ ${ }^{5}$ Universidade Estadual de Maringá, Departamento de Adminstração, Maringá, PR, Brazil.
}

\begin{abstract}
The objective of this paper was to analyze financial management practices in dairy production systems. More specifically, we sought to identify which milk producers adopt financial management practices. We conducted 55 semistructured questionnaires in the Western Region of Paraná. The data were processed through descriptive and multivariate statistical analysis. The analysis of hierarchical clusters defined, based on variables related to financial management practices, two distinct groups. The first group included milk producers who do not adopt financial management practices $(\mathrm{N}=49)$ and the second group described the milk producers who do adopt these practices $(\mathrm{N}=6)$. We then used Common Factor Analysis, along with structural, technical, productive, and socioeconomic variables to define the three factors that best explained the variance between the clusters: factor 1 - structural; factor 2 - social; factor 3 - informational. Smaller dairy production systems, with lower production, managed by younger producers, and employing younger workers, are those adopting financial management practices. Therefore, the scarcity of resources is not a limiting factor in the adoption of financial management practices.
\end{abstract}

Key Words: cluster, costs, factor analysis

\section{Introduction}

Despite the economic and social importance of Brazilian milk production, the dairy industry still faces obstacles, including management deficiencies and lack of planning in rural properties (FBB and IICA, 2010). The efficiency, competitiveness, and sustainability of rural enterprises rest on their management capacity (Seymour and Barr, 2014). Despite their importance, financial management tools are not widely used in the Brazilian agricultural sector (Nantes and Scarpelli, 2007; MAPA, 2011). In 2015, a project conducted by the Ministério da Agricultura, Pecuária e Abastecimento (MAPA) to improve the competitiveness of the Brazilian dairy sector, highlighted the importance of rural property management

Received: October 14, 2016

Accepted: February 6, 2017

*Corresponding author: fibankuti@uem.br

http://dx.doi.org/10.1590/S1806-92902017000500008

How to cite: Zimpel, R.; Bánkuti, F. I.; Zambom, M. A.; Kuwahara, K. C. and Bánkuti, S. M. S. 2017. Characteristics of the dairy farmers who perform financial management in Paraná State, Brazil. Revista Brasileira de Zootecnia 46(5):421-428.

Copyright (C) 2017 Sociedade Brasileira de Zootecnia. This is an Open Access article distributed under the terms of the Creative Commons Attribution License (http://creativecommons.org/licenses/by/4.0/), which permits unrestricted use, distribution, and reproduction in any medium, provided the original work is properly cited. as a development axis for the five main producing states (MAPA, 2011; Abreu, 2015).

The state of Paraná is the third largest milk producer in Brazil. It produced 4.53 billion liters of milk in 2014, or $13 \%$ of the national production. Considering the importance of dairy farming for family employment and income, the state sees actions for management improvement as a priority (EMATER, 2014).

Despite the importance of economic management in dairy production systems (DPS) (Oliveira et al., 2007; McDonald et al., 2013), previous studies have underlined difficulties and management failures in Brazil and around the world (Godinho et al., 2013; Kajananthan and Achchuthan, 2013; Cyrne et al., 2015a; Cyrne et al., 2015b). Animal-performance indicators are frequently prioritized for DPS monitoring and performance evaluation (Sousa et al., 2011; Lopes Junior et al., 2012; Ruberto et al., 2013). However, the usefulness of these indicators rests on their systematic assessment along with other indicators (Godinho and Carvalho, 2009). The complexity of DPS is due to several variables such as production, technology, infrastructure, market, and management. Their performance relies on the combination of these elements (FBB and IICA, 2010) and their complexity is reinforced due to differences in DPS across Paraná (IPARDES, 2009; Bodenmüller Filho et al., 2010). 
The objective of this study was to analyze financial management practices in dairy production systems. More specifically, we sought to identify the characteristics of the milk producers who adopt financial management practices. The classification of these attributes may support public and private incentive actions and training opportunities for the improvement of financial management techniques in DPS, as well as guidelines for rural extension.

\section{Material and Methods}

From September 2013 to April 2014, we applied semi-structured questionnaires to 55 DPS in the Western Region of Paraná. This area is the largest milk producer of Paraná, generating 1.09 billion liters in 2014 (IBGE, 2015). To define the DPS for this study, we used random selection. We collected structural, productive, and technical information, in addition to DPS management and socioeconomic variables from their managers, the farmers (Table 1) (Brito et al., 2015; Yabe et al., 2015).

The variables were arranged and statistically analyzed using the software SPSS (Statistical Package for Social Sciences, version 18). First, we used descriptive statistical analysis to characterize the DPS and their managers by including technical, structural, and productive variables. Next, we performed hierarchical cluster analysis.

Hierarchical cluster analysis is a technique of interdependency, used to group elements or variables presenting high similarities and high differences from the others. This analysis results in the formation of clusters with internal elements strongly similar but with highly diverse elements in other groups (Fávero et al., 2009). Homogeneity among elements follows parameters set by the researcher and according to a distance measure. For the present research, we adopted the Euclidean distance (Fávero et al., 2009; Hair et al., 2009).

For the cluster analysis, it was assumed that the financial management of farms is associated with different techniques and tools (Colleta et al., 2013). We therefore considered three variables on financial management practices: use of specific software for financial management, establishment of cash flow for dairy farming, and use of other tools for financial management. The cluster analysis led to the creation of two groups. We then performed a proportions test ( $\mathrm{P}$ test) on the defining variables of the clusters to verify differences in the adoption of practices for financial management to a $5 \%$ significance level.

In the second part of our analysis, we conducted Common Factor Analysis (CFA) (Hostiou et al., 2006; Carrillo et al., 2011).
Common Factor Analysis is a multivariate technique used to combine a large set of interrelated variables into a smaller number of factors. A factor objectively represents the different variables compounding it. Each factor is formed by variables presenting high correlation among them and low correlation with variables forming other factors (Fávero et al., 2009; Hair et al., 2009). Factor analysis states the following assumptions:

Common factors $\left(\mathrm{F}_{\mathrm{k}}\right)$ are independent and equally distributed, with mean 0 and variance $1(\mathrm{k}=1, \ldots, \mathrm{m})$;

1- Errors $\left(\varepsilon_{\mathrm{i}}\right)$ are independent and equally distributed, with mean 0 and variance $\psi i(i=1, \ldots, p)$;

2- $\mathrm{F}_{\mathrm{k}}$ and $\varepsilon_{\mathrm{i}}$ are independent.

Factors are estimated through the combination of linear variables, as in equation 1 :

$$
\begin{gathered}
\mathrm{F}_{1}=d_{11}+X_{1}+d_{12}+X_{2}+\ldots+d_{1 m}+X_{i} \\
\mathrm{~F}_{2}=d_{21}+X_{1}+d_{22}+X_{2}+\ldots+d_{2 m}+X_{i} \\
\vdots \\
\mathrm{F}_{m}=d_{\mathrm{m} 1}+X_{1}+d_{\mathrm{m} 2}+X_{2}+\ldots+d_{m i}+X_{i},
\end{gathered}
$$

in which $\mathrm{F}_{m}=$ common factors, $d_{m i}=$ coefficient of factor scores, and $X_{i}=$ original variables.

Factor analysis model is presented in equation 2:

$$
\begin{gathered}
X_{1}=\mu_{1}+a_{11} F_{1}+a_{12} F_{2}+\ldots+a_{1 m} F_{m}+\varepsilon_{1} \\
X_{2}=\mu_{2}+a_{21} F_{1}+a_{22} F_{2}+\ldots+a_{2 m} F_{m}+\varepsilon_{2} \\
\vdots \\
X_{p}=\mu_{p}+a_{p 1} F_{1}+a_{p 2} F_{2}+\ldots+a_{p m} F_{m}+\varepsilon_{p},
\end{gathered}
$$

in which $\mu_{p}=$ mean vector, $a_{i j}=$ loading, $X_{i}=$ variable, $F_{m}=$ common factor, and $\varepsilon_{\mathrm{i}}=$ error.

Considering the standardization of $\mathrm{X}$ (mean 0 and standard deviation 1), Factor Analysis model can be generically presented as in equation 3 :

$$
X_{i}=a_{i 1} F_{1}+a_{i 2} F_{2}+\ldots+a_{i m} F_{m}+\varepsilon_{i}, \quad(i=1, \ldots, p)
$$

For Common Factor Analysis, we used 23 productive, structural, technical, and socioeconomic variables of DPS and their managers.

The extraction method of the principal component analysis used the Varimax rotation type, Kaiser Meyer Olkin standardization (to select the number of factors, we employed the Kaiser criterion, which retains the variables with eigenvalues above 1.0 (Fávero et al., 2009; Hair et al., 2009) and Bartlett sphericity test (Barroso and Arts, 2003; Hair et al., 2009). To determine the number of factors to be retained in the analysis, we used the criteria of a minimum accumulated variance of $60 \%$ and eigenvalues higher than 1.0 for each factor (Fávero et al., 2009; Hair et al., 2009).

Eigenvalues represent how much each factor explains total variance. Once variables are standardized, with mean 0 and variance 1 , the selection of factors with eigenvalues higher than 1 indicates that the factor explains the variance 
of at least one variable in the model. Thus, only factors presenting eigenvalues higher than 1 are significant $(\mathrm{P}<0.05)$ (Fávero et al., 2009).

The selection of variables compounding each factor is considered the factor loading. Variables presenting low or medium factor loading were suppressed from the analysis (Hair et al., 2009).

Consistent with these criteria, 11 variables remained in the CFA.

The DPS were plotted on two-dimensional graphs using the factor scores and the classification of DPS in each of the groups defined by the clustering analysis. Common Factor Analysis generates factor scores, which can be treated as variables, which describe how much an individual would score in a factor (Yong and Pearce, 2013).

Using this procedure, we analyzed the distribution of DPS belonging to the different groups, considering structural, productive, technical, and socioeconomic characteristics.

The combined use of factor and cluster analysis has been widely used in animal production systems for several purposes, including the evaluation of regionalization, production dynamics, and typology of production systems (Escobar and Berdegué, 1990; Bernués et al., 2003;
Delgado et al., 2003; Llanillo et al., 2006; Barnes and Toma, 2012; Mattos and Santana, 2014; Rivas et al., 2015).

\section{Results}

For the 55 DPS analyzed, the age of producers ranged from 20-71 years, with a mean of 43.6 years. The respondents had been working in agriculture for 33.4 years on average. Furthermore, they had been associated with the dairy sector for 3-40 years and, on average, had worked for 17 years in this sector. This information agrees with previous studies (IPARDES, 2009; Brito et al., 2015) and highlights the heterogeneity of producers in Paraná, with experience in the area and consequent accumulation of knowledge, which may favor the adoption of financial management practices.

The area of the properties ranged from 2-211 ha, or 34.3 ha on average, which means that most of them are characterized as small farms. The definition of a small property is that it has up to four fiscal modules, which corresponds to 72 ha in the studied area (IAP, 2014). The pasture area for milk production varied from 1-60 ha, with a mean value of 6.49 ha. The total number of dairy cattle in each DPS ranged from 3-200, averaging 80 head/DPS. The volume of milk ranged from 40-1900 L/day in each DPS, or

Table 1 - Variables of Common Factor Analysis

\begin{tabular}{|c|c|c|}
\hline Variable & Response & Type \\
\hline 1- Total area (ha) ${ }^{1}$ & Absolute value & Metric \\
\hline 2- Pasture area (ha) & Absolute value & Metric \\
\hline 3 - Area of forage production $(\text { ha })^{1}$ & Absolute value & Metric \\
\hline 4- Number of dairy cattle (heads) ${ }^{1}$ & Absolute value & Metric \\
\hline 5- Number of lactating cows (heads) ${ }^{1}$ & Absolute value & Metric \\
\hline \multirow[t]{2}{*}{ 6- Daily production of milk (L/milk/day) ${ }^{1}$} & Absolute value & Metric \\
\hline & Natural breeding & \\
\hline \multirow[t]{3}{*}{ 7- Reproductive technique } & Controlled breeding & Ordinal \\
\hline & Artificial insemination & \\
\hline & Transfer of embryos & \\
\hline 8- Time in farming activity (years) ${ }^{1}$ & Absolute value & Metric \\
\hline 9- Time in dairy farming (years) ${ }^{1}$ & Absolute value & Metric \\
\hline 10- Age of farmer (years) ${ }^{1}$ & Absolute value & Metric \\
\hline 11- Age of farm workers (years) ${ }^{1}$ & Absolute value & Metric \\
\hline 12- Educational level of farmer (years of study) & Absolute value & Metric \\
\hline 13- Knows what is evaluated on milk quality & Yes/No & Dummy \\
\hline 14- Knows the average SCC value of milk & Yes/No & Dummy \\
\hline 15- Knows the average TBC value of milk & Yes/No & Dummy \\
\hline 16- Knows the average value of milk protein & Yes/No & Dummy \\
\hline 17- Knows the average value of milk fats & Yes/No & Dummy \\
\hline 18- Knows the fixed asset in dairy farming & Yes/No & Dummy \\
\hline 19- Knows the financial return of dairy farming & Yes/No & Dummy \\
\hline 20- Knows the cost composition of dairy farming & Yes/No & Dummy \\
\hline 21- Knows the cost of milk production & Yes/No & Dummy \\
\hline 22- Knows the cost of concentrate ${ }^{1}$ & Yes/No & Dummy \\
\hline 23- Knows the cost of medicines ${ }^{1}$ & Yes/No & Dummy \\
\hline
\end{tabular}

SCC - somatic cell count; TBC - total bacteria count.

${ }^{1} \mathrm{Kept}$ in the Common Factor Analysis. 
$678 \mathrm{~L} /$ day/DPS on average. These data indicate technical and productive heterogeneity in the DPS, which is in agreement with the findings of Bodenmüller Filho et al. (2010).

Cluster analysis created two groups based on the three variables related to the adoption of financial management practices: group 1 consisted of $89.1 \%$ of the DPS (49 producers) and group 2 was formed by six DPS, which was $10.9 \%$ of the total. Our data show that group 1 is composed of DPS with low use of financial management practices while group 2 gathers DPS with intensive financial management practices (Table 2). At the 5\% significance level, the groups differed statistically for the three variables related to financial management practices (Table 2).

The entirety of DPS in the second group uses specific software for financial management, whereas none of the DPS in the first group did so (Table 2). In addition to using software for financial control, farmers could use it to complete financial transactions. Among the respondents, $54.5 \%$ do not perform cash flow and cash flow is less common in group 1 than in group 2 (Table 2). This result corroborates other findings on the limited use of cash flow by rural producers (Cyrne et al., 2015a; Cyrne et al. 2015b; Lisboa et al., 2015).

Finally, $65.5 \%$ of the analyzed farmers do not use any other tool for financial management such as spreadsheets or manual techniques for cost management. Within group $1,26.5 \%$ of the producers adopted one of these methods, while all producers in group 2 did so (Table 2).

For the second part of our study, we used CFA, which resulted in a Kaiser Meyer Olkin value of 0.687 and a Bartlett test score of 0.000 , indicating the relevance of the chosen variables to the method employed. The results indicate that the three factors explain $72.28 \%$ of the total variance among the 55 DPS (Table 3), satisfying the minimum criteria established for this analysis (Hair et al., 2009). Factor 1 (F1) is the main factor when creating a difference among the DPS analyzed.

Factor 1, named as the "structural factor", consisted of variables related to the structure of the DPS, such as "total area", "forage area for milk production", "milk volume produced", "total number of cattle", and "number of lactating cows" (Table 4). This factor can influence the production success and the financial results of each DPS.
Therefore, F1 is an indication of reinvestment capacity, production adjustment, possibility of training for financial management, among others (Lourenzani and Silva, 2009; Godinho et al., 2013).

Factor 2 (F2) consisted of variables related to the social characteristics of the farmer, including "age of farmer", "time spent in farming activity", "time spent in dairy farming", and "age of farm workers" (Table 4). Thus, this factor was designated as the "social factor" and can be used as an indicator of the relationship between age and accumulated experience and financial management practices.

Factor 3 (F3), referred to as the "informational factor", was defined by the following variables: "knows the cost of concentrate" and "knows the costs of medications" (Table 4). This factor indicates the degree of knowledge of the producer about the costs of important inputs to dairy farming. We recognized that the knowledge of production costs was an essential step for proper financial management. It is important to emphasize that feeding costs can represent up to two-thirds of the operating expenses of DPS (Lopes et al., 2010).

The DPS were plotted using the factor scores and the grouping formed by the cluster analysis, allowing the visualization of productive, technical, structural, social, and informational characteristics in each group (Figures 1 and 2).

The DPS in group 1 are very heterogeneous in their structural and social factors (Figure 1). This means that a lack of adoption of financial management practices is present in producers of different sizes and production volumes and also of different ages and experience. This heterogeneity was expected, since it is a characteristic of dairy farming in general and the majority of the producers interviewed were in group 1. The DPS in group 2, those practicing financial management, are less heterogeneous. Most of these DPS are situated in the third quadrant, indicating that they are composed of producers with lower scores for structural and social characteristics (Figure 1).

For F3, the "informational factor", the DPS in groups 1 and 2 are very heterogeneous and most of the producers do not know the costs of important inputs to milk production (Figure 2); these results are consistent with those presented

Table 2 - Adoption of financial management practices according to producer groups

\begin{tabular}{lcc}
\hline Variable & Group 1 (\%) & Group 2(\%) \\
\hline Use of specific software(s) for financial management & 0.0 & 100.0 \\
Development of cash flow for financial management & 40.8 & 83.3 \\
Use of other tools for financial management & 26.5 & 0.0000 \\
\hline
\end{tabular}

Group 1 consists of $89.1 \%$ of dairy production systems (49 producers); Group 2 is formed by six dairy production systems, or $10.9 \%$ of the total. 
by Mazzioni et al. (2007). Within group 1, some producers who do not adopt financial management practices have knowledge of input costs.

Conversely, some producers conduct financial management (group 1), but do not know the input costs (Figure 2). This may indicate that, despite using techniques and tools for financial management, these DPS still have management weaknesses.

Table 3 - Total variance explained

\begin{tabular}{lccc}
\hline \multirow{2}{*}{ Factor } & \multicolumn{3}{c}{ Initial eigenvalue } \\
\cline { 2 - 4 } & Total & Variance (\%) & Cumulative percentage \\
\hline F1 & 3.527 & 32.066 & 32.066 \\
F2 & 2.896 & 26.326 & 58.393 \\
F3 & 1.527 & 13.878 & 72.271 \\
\hline
\end{tabular}

F1, the "structural factor", consists of variables related to the structure of the dairy production systems; F2, the "social factor", consists of variables related to the social characteristics of the farmer; F3, the "informational factor", indicates the degree of knowledge of the producer about the costs of important inputs to dairy farming.

Table 4 - Factor loading

\begin{tabular}{lrrr}
\hline \multirow{2}{*}{ Variable } & \multicolumn{3}{c}{ Factor } \\
\cline { 2 - 4 } & \multicolumn{1}{c}{1} & \multicolumn{1}{c}{2} & \multicolumn{1}{c}{3} \\
\hline Total area (ha) & 0.578 & -0.046 & -0.173 \\
Age of farmer (years) & 0.015 & 0.894 & -0.027 \\
Time in farming activity (years) & -0.040 & 0.824 & -0.163 \\
Time in dairy farming (years) & -0.011 & 0.794 & -0.046 \\
Age of farm workers (years) & 0.066 & 0.794 & -0.048 \\
Forage area for milk production (ha) & 0.815 & 0.150 & -0.312 \\
Daily production of milk (kg/day) & 0.885 & -0.012 & 0.116 \\
Number of dairy cattle (heads) & 0.906 & -0.050 & 0.090 \\
Number of lactating cows (heads) & 0.912 & 0.049 & 0.023 \\
Knows the cost of concentrate & -0.079 & -0.075 & 0.870 \\
Knows the cost of medications & -0.023 & -0.129 & 0.879 \\
\hline
\end{tabular}

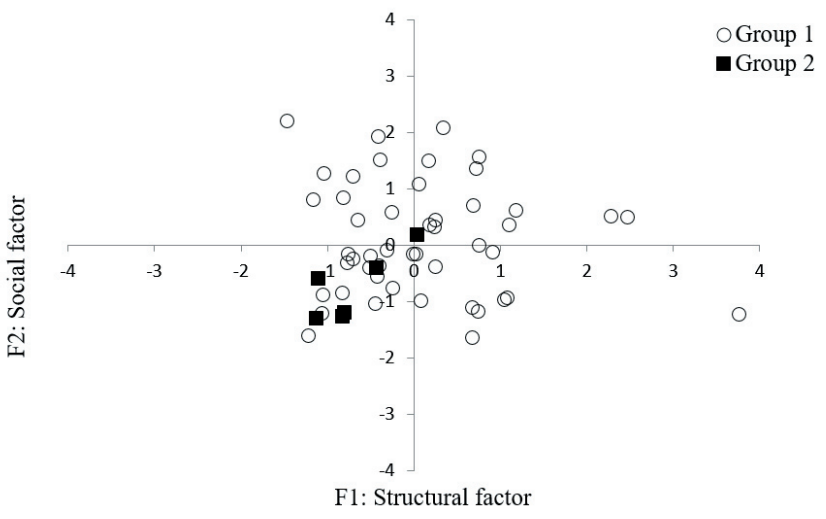

Group 1 consists of $89.1 \%$ of dairy production systems (49 producers); Group 2 is formed by six dairy production systems, or $10.9 \%$ of the total; F1, the "structural factor", consists of variables related to the structure of the dairy production systems; F2, the "social factor", consists of variables related to the social characteristics of the farmer.

Figure 1 - Dairy production systems in groups 1 and 2 compared to factor 1 (F1) and factor 2 (F2).

\section{Discussion}

Overall, the use of financial management in the analyzed DPS is scarce and more than half (51\%) of group 1 producers do not use any financial management practice. This finding supports the results of previous investigations indicating low rates of financial management practice in agricultural activity (Viana and Rinaldi, 2010; Almeida et al., 2011; Sousa et al., 2011; Godinho et al., 2013; Lisboa et al., 2015). This deficiency may compromise the maintenance of DPS in the medium and long term (Nachiluk and Oliveira, 2012; Gonçalves et al., 2014), especially because the lack of financial management may influence the family succession.

Previous studies have indicated that even with internet and computer access, the use of software for management of rural properties is not observed (Barcelos et al., 2014; Deponti, 2014). Indeed, it seems that the minimal use of software for management is not necessarily due to a lack of access to Information and Communication Technology. Marion and Segatti (2006) and Barcelos et al. (2014) point out the need for developing appropriate management systems that fit the necessities and particularities of farmers and the absence of such systems may be a cause of their low implementation among the surveyed farmers.

The use of other techniques and tools for financial management by group 2 producers may indicate that the specific software for financial management of the agricultural sector is not adequate, which aligns with previous research (Buainain et al., 2005; Barcelos et al., 2014; Deponti, 2014). Several factors may contribute to

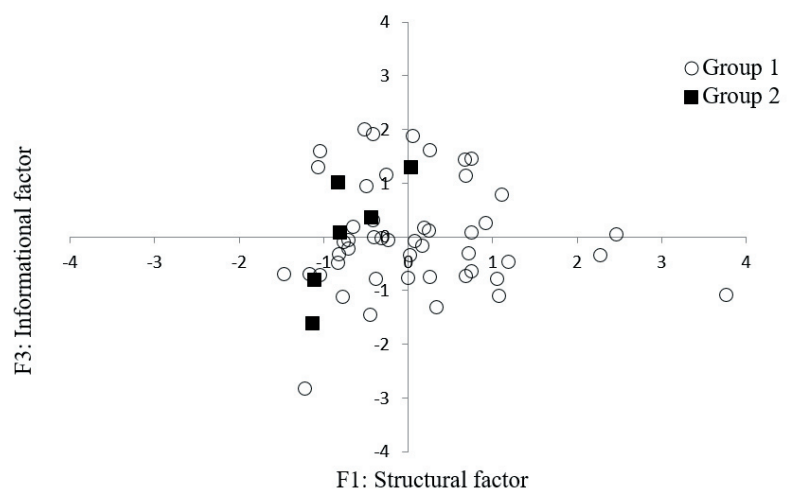

Group 1 consists of $89.1 \%$ of dairy production systems (49 producers); Group 2 is formed by six dairy production systems, or $10.9 \%$ of the total; F1, the "structural factor", consists of variables related to the structure of the dairy production systems; F3, the "informational factor", indicates the degree of knowledge of the producer about the costs of important inputs to dairy farming.

Figure 2 - Dairy production systems in groups 1 and 2 compared to factor 1 (F1) and factor 3 (F3). 
the reduced use of financial management techniques in rural enterprises, including a lack of training and technical assistance, access barriers, and cultural aspects (Buainain et al., 2005; Mazzioni et al., 2007; Lourenzani and Silva, 2009; Almeida et al., 2011).

Producers who use financial management techniques are those with a smaller area for production, fewer animals, and lower production volume. Even though Godinho et al. (2013) observed that the adoption of planning techniques and management of dairy farming is associated with the largest production scale, since major producers have more resources available for that purpose, our research shows that small-scale producers are more dedicated to financial management. These producers may have a greater need to conduct DPS financial management, as small-scale production offers them lower margins for management inefficiencies. Indeed, producers with reduced availability of resources do not have a wide margin for losses and may require a more refined financial management, given that minor flaws in investments and returns can bring substantial consequences for the business. Additionally, the economic dependence on dairy farming has a tendency to be higher for small producers.

Group 2 is also characterized by younger farmers with less cumulative experience in agriculture and dairy farming. This finding supports the results of other studies: younger producers are more engaged in the financial management of rural enterprises, especially when it involves the use of software and information technology tools (Colleta et al., 2013). Younger producers tend to absorb new management practices easily, which, in many cases, depends on the use of software and tools that do not match with older models of production system management.

Despite their experience, older farmers may present path dependence and impose barriers to technological and productive changes (Buainain et al., 2005), which is intensified by inherent conservative profile and cultural aspects of the farmers (Mazzioni et al., 2007; Almeida et al., 2011). Such barriers are even more important in dynamic environments and markets, where production conditions, technology, and demand frequently change, such as in the Brazilian dairy system.

Results also indicate that even when producers record the costs in their spreadsheets and financial management software, they do not necessarily make proper use of the information. This result may imply that managers of DPS in group 2 are registering input costs but not effectively using this information for decision making, which was also observed by Cyrne et al. (2015a). Despite adding input costs to the financial management system, milk producers seem to care more about the output information of the system, such as return and profit. Failing to use input information demonstrates a higher concern with monitoring the financial performance of the DPS than in making improvement decisions.

Our findings show that smaller DPS with lower production, managed by younger producers, and employing younger workers, are those that strongly adopt financial management practices. However, not all producers who use financial management know the costs of inputs, indicating failures throughout this economic control.

The adoption of financial management practices has been heavily associated with the need for management of scarce resources instead of considering the high availability of resources for this purpose. Those that use financial management are younger farmers who have been working in the dairy industry for a shorter period; so, they are not as embedded in older models of management as the farmers with more experience.

\section{Conclusions}

In general, dairy production system managers do not adopt financial management practices in Paraná. Only a small group, comprising smaller dairy production systems with lower production, managed by young producers, and employing younger labor, apply financial management practices. The lack of resources does not seem to be a limiting factor; instead, it may encourage small dairy production systems, with fewer resources, to improve management practices. Considering the importance of financial management in rural sector, the low adoption of financial management practices in dairy activity may indicate complications for economic sustainability of dairy production systems in the long run. Public and private policies may direct the development of more suitable tools, techniques, and software, as well as encourage farmers to adopt these tools. This may enable better management at the farm level and promote gains in performance and competitiveness for dairy sector in Paraná.

\section{References}

Abreu, K. 2015. Projeto de melhoria da competitividade do setor lácteo brasileiro. Brasilia, DF. Available at: $<$ http://www.agricultura.gov. br/arq_editor/MAPA-Projeto setor lacteo.pdf.>. Accessed on: June 10, 2016.

Almeida, L. B.; Costa, F. M. G.; Panhoca, L.; Gomes, G. A. and Robazza, W. S. 2011. Práticas de controles gerenciais pelos produtores de leite no Oeste de Santa Catarina que adotam o método 
de Pastoreio Racional Voisin (PRV). Custos e Agronegocio online 7:120-139. Available at: <http://www.custoseagronegocioonline. com.br/numero1v7/controlesgerenciais.pdf $>$. Accessed on: Dec. 12, 2015 .

Barcelos, L. S.; Silva, G. A.; Ritt, D.; Lubaczwski, A. and Deponti, C. M. 2014. Agricultura familiar e tecnologias de informação e comunicação (Tics): Projeto Piloto Vale Do Caí. JRevista Jovens Pesquisadores 4:106-117.

Barnes, A. P. and Toma, L. 2012. A typology of dairy farmer perceptions towards climate change. Climatic Change 112:507-522. doi:10.1007/s10584-011-0226-2.

Barroso, L. P. and Artes, R. 2003. Análise multivariada. Universidade Federal de Lavras, Lavras.

Bernués, A.; Olaizola, A. and Corcoran, K. 2003. Labelling information demanded by european consumers and relationships with purchasing motives, quality and safety of meat. Meat Science 65:1095-1106. doi: 10.1016/S0309-1740(02)00327-3.

Bodenmüller Filho, A.; Damasceno, J. C.; Previdelli, I. T. S.; Santana, R. G.; Ramos, C. E. C. O. and Santos, G. T. 2010. Tipologia de sistemas de produção baseada nas características do leite. Revista Brasileira de Zootecnia 39:1832-1839. doi:10.1590/S151635982010000800028.

Brito, M. M.; Bánkuti, F. I.; Bánkuti, S. M. S.; Santos, G. T.; Damasceno, J. C. and Massuda, E. M. 2015. Horizontal arrangements and competitiveness of small-scale dairy farmers in Paraná, Brazil. International Food and Agribusiness Management Review 18:18.

Buainain, A. M.; Batalha, M. O. and Souza Filho, H. M. 2005. Tecnologia de gestão e agricultura familiar. p.43-66. In: Gestão integrada da agricultura familiar. Batalha M. O. and Souza Filho, H. M., eds. EdUFSCar, São Carlos, SP.

Carrillo L., B.; Moreira L., V. H. and González V., J. 2011. Caracterización y tipificación de sistemas productivos de leche en la zona Centro-Sur de Chile: un análisis multivariable. Idesia (Arica) 29:71-81. doi: 10.4067/S0718-34292011000100010.

Colleta, B. K. D.; Cezar, I. M.; Souza, C. C. and Costa, F. P. 2013. Instrumentos de gestão financeira utilizados pelos produtores de grãos de São Gabriel do Oeste, Mato Grosso do Sul. Revista Agrarian 6:346-357.

Cyrne, C. C. S.; Haetinger, C. and Rempel, C. 2015a. O (não) uso de indicadores de gestão em propriedades leiteiras do Vale do Taquari - RS. Estudo \& Debate 22:128-142.

Cyrne, C. C. S.; Rempel, C.; Haetinger, C. and Bortoli, J. 2015b. O (não) uso de indicadores de gestão em propriedades leiteiras na Galícia - Espanha. Holos 31:307-21. doi: 10.15628/holos.2015.3249.

Delgado, C. L.; Narrod, C. A. and Tiongco, M. M. 2003. Implications of the scaling-up of livestock production in a group of fast-growing developing countries. Livestock and Livelihoods. International Food Policy Research Institute, Washington, DC; and Food and Agriculture Organization of the United Nations, Rome.

Deponti, C. M. 2014. As 'agruras' da gestão da propriedade rural pela agricultura familiar. Redes - Revista de Desenvolvimento Regional 19(ed. especial):9-24.

EMATER - Instituto Paranaense de Assistência Técnica e Extensão Rural. 2014. Projeto bovinocultura de leite - Resumo executivo. Curitiba, PR. Available at: <http://www.emater.pr.gov.br/modules/ conteudo/conteudo.php?conteudo=69>. Accessed on: Aug. 13, 2015.

Fávero, L. P.; Belfiore, P. P.; Silva, F. L. and Chan, B. L. 2009. Análise de dados: modelagem multivariada para tomada de decisões. p.1-18. In: Análise de dados: Modelagem multivariada para tomada de decisões. 3.ed. Elsevier, Rio de Janeiro.

FBB - Fundação Banco do Brasil, and IICA - Instituto Interamericano de Cooperação para Agricultura. 2010. Desenvolvimento regional sustentável - Bovinocultura de Leite. v.1. Brasília.
Escobar, G. and Berdegué, J. 1990. Tipificación de sistemas de producción agrícola. RIMISP, Santiago de Chile.

Godinho, R. F. and Carvalho, R. C. R. 2009. Gestão de sistemas de produção de leite. Ciência et Praxis 2:77-82.

Godinho, R. F.; Soares, V. E.; Bertipaglia, L. M. A. and Dian, P. H. M. 2013. Gestão empresarial em sistemas de produção de leite na microregião de São João Batista do Glória (MG). Ciência et Praxis 6:39-50.

Gonçalves, A. C. S.; Roma Júnior, L. C.; Fonseca, M. I.; Nadruz, B. V.; Bürger, K. P. and Rossi, G. A. M. 2014. Assistência técnica e extensão rural: sua importância para a melhoria da produção leiteira. Relato de caso. Revista Brasileira de Higiene e Sanidade Animal 8:47-61. doi: 10.5935/1981-2965.20140116.

Hair, J. F. Jr.; Black, W. C.; Babin, B. J. and Anderson, R. E. 2009. Multivariate data analysis. 7th ed. Prentice Hall, Saddle River.

Hostiou, N.; Veiga, J. B. and Tourrand. J. F. 2006. Dinâmica e evolução de sistemas familiares de produção leiteira em Uruará, frente de colonização da Amazônia brasileira. Revista de Economia e Sociologia Rural 44:295-311. doi: 10.1590/S010320032006000200007.

IAP - Instituto Ambiental do Paraná. 2014. Módulos fiscais dos municípios do Estado do Paraná. Available at: $<$ http://www.iap. pr.gov.br/modules/conteudo/conteudo.php?conteudo=1328>. Accessed on: May 5, 2015.

IPARDES - Instituto Paranaense de Desenvolvimento Econômico e Social. 2009. Caracterização socioeconômica da atividade leiteira no Paraná. Available at: <http://www.ipardes.gov.br/biblioteca/ docs/sumario_executivo_atividade leiteira parana.pdf $>$. Accessed on: Mar. 20, 2015.

IBGE - Instituto Brasileiro de Geografia e Estatística. 2015. Pesquisa da pecuária municipal. 2015. Available at: <www.ibge.gov.br>. Accessed on: Oct. 8, 2015.

Kajananthan, R. and Achchuthan, S. 2013. Marketing challenges in dairy and Paddy Sector Development. Individual farmers perspective: Evidence from Sri Lanka. Journal of Economics and Sustainable Development 4:150-158.

Lisboa, F. C.; Medeiros, M. H.; Peixoto, J. L. M.; Gouveia, L. C. and Nascimento, W. R. 2015. Diagnóstico do uso de ferramentas de gestão por proprietários rurais de Uberlândia - MG. Revista Verde de Agroecologia e Desenvolvimento Sustentável 10:132-138. doi:10.18378/rvads.v10i2.3287.

Llanillo, R. F.; Del Grossi, M. E.; Santos, F. O.; Munhos, P. D. and Guimarães, M. F. 2006. Regionalização da agricultura do Estado do Paraná, Brasil. Ciência Rural 36:120-127. doi:10.1590/S010384782006000100018 .

Lopes Junior, J. F.; Ramos, C. E. C. O.; Santos, G. T.; Grande, P. A.; Damasceno, J. C. and Massuda, E. M. 2012. Análise das práticas de produtores em sistemas de produção leiteiros e seus resultados na produção e qualidade do leite. Semina: Ciências Agrárias 33:1199-1208. doi: 10.5433/1679-0359.2012v33n3p1199.

Lopes, M. A.; Dias, A. S.; Carvalho, F. M.; Lima, A. L. R.; Cardoso, M. G. and Carmo, E. A. 2010. Efeito do tipo de mão-de-obra nos resultados econômicos de sistemas de produção de leite na região de Lavras (MG). Revista Brasileira de Agrociência 16:125-132. doi: 10.18539/CAST.V16I1-4.2020.

Lourenzani, W. L. and Silva, C. A. B. 2009. Analyzing the economic sustainability of small scale agroindustrial entreprises: A system dynamics approach. Revista Brasileira de Agroinformática 9:28-40.

MAPA - Ministério da Agricultura, Pecuária e Abastecimento. 2011. Agenda estratégica 2010-2015 leite e derivados. Brasília, DF.

Marion, J. C. and Segatti, S. 2006. Sistema de gestão de custos nas pequenas propriedades leiteiras. Custos e Agronegócio Online 2:2-7. 
Mattos, C. A. C. and Santana, A. C. 2014. As contribuições da pecuária leiteira para os agricultores familiares: um estudo no Sudeste do Estado do Pará. Revista Extensão Rural 20:56-71.

Mazzioni, S.; Zanin, A.; Kruger, S. D. and Rocha, J. L. K. 2007. A importância dos controles gerenciais para o Agribusiness. Revista Catarinense da Ciência Contábil 6:9-26. doi: 10.16930/2237-7662/ recc.v6n16p9-26.

McDonald, R.; Shalloo, L; Pierce, K. M. and Horan, B. 2013. Evaluating expansion strategies for startup European Union dairy farm businesses. Journal of Dairy Science 96:4059-4069. doi: 10.3168/jds.2012-6365.

Nachiluk, K. and Oliveira, M. D. M. 2012. Custo de produção: Uma importante ferramenta gerencial na agropecuária. Análises e Indicadores do Agronegócio 7:1-10.

Nantes, J. F. and Scarpelli, M. 2007. Gestão da produção rural no agronegócio. p.556-584. In: Gestão agroindustrial. 3.ed. Batalha, M. O., ed. Atlas, São Paulo.

Oliveira, A. S.; Cunha, D. N. F. V.; Campos, J. M. S.; Vale, S. M. L. R. and Assis, A. J. 2007. Identificação e quantificação de indicadoresreferência de sistemas de produção de leite. Revista Brasileira de Zootecnia 36:507-516. doi: 10.1590/S1516-35982007000200030.

Rivas, J.; Perea, J.; Angón, E.; Barba, C.; Morantes, M.; DiosPalomares, R.; and García, A. 2015. Diversity in the dry land mixed system and viability of dairy sheep farming. Italian Journal of Animal Science 14:179-186. doi: 10.4081/ijas.2015.3513.
Ruberto, I. V. G.; Mareth, T.; Paim, E. S. E. and Pieniz, L. P. 2013. Contribuição da programação linear na gestão de custos e na produtividade em uma propriedade rural. Custos e Agronegócio Online 9:185-202. Available at: <http://www. custoseagronegocioonline.com.br/numero1v9/Programacaolinear. pdf $>$. Accessed on: Feb. 10, 2015.

Seymour, E. and Barr, N. 2014. Farmer preferences for formal learning: A review of current data and literature. Rural and Resources Policy. doi: 10.13140/RG.2.1.3197.9684.

Sousa, M. R. P.; Ristow, A. M.; Nogueira, E. B.; Torres Filho, R. A. and Cortez, M. A. S. 2011. Caracterização de pequenas unidades produtoras de leite na região Centro e Noroeste do estado do Rio de Janeiro. Revista Brasileira de Ciência Veterinária 18:79-84. doi: $10.4322 / \mathrm{rbcv} .2014 .124$

Viana, G. and Rinaldi, R. N. 2010. Principais fatores que influenciam o desempenho da cadeia produtiva de leite - um estudo com os produtores de leite do município de Laranjeiras do Sul-PR. Organizações Rurais \& Agroindustriais 12:263-274.

Yabe, M. T.; Bánkuti, F. I.; Damasceno, J. C. and Brito, M. M.. 2015. Characteristics of milk production systems and feed strategies for dairy cows in the North and Northwest of Paraná State. Semina: Ciências Agrárias 36:4469-4480. doi: 10.5433/1679-0359.2015v3 6n6Supl2p4469.

Yong, A. G. and Pearce, S. 2013. A beginner's guide to factor analysis: Focusing on exploratory factor analysis. Tutorials in Quantitative Methods for Psychology 9:79-94. 